\title{
Um altar romano na baía do Guajará: programa iconológico e reforma católica na Catedral da Sé de Belém do Pará (1867-1892)
}

\author{
A Roman altar in the bay of Guajará: An iconological programme \\ and Catholic reform in the Cathedral of Belém do Pará (1867-1892)
}

\begin{abstract}
Resumo
Este artigo analisa o papel da arte sacra e religiosa na Amazônia no contexto do movimento de renovação do catolicismo brasileiro no século XIX, conhecido como reforma católica Para isso, toma, como objeto de análise, a encomenda do altar mor de Nossa Senhora de Belém pelo bispo do Pará D. Antônio de Macedo Costa (1830-1891) para o escultor e arquiteto italiano Luca Carimini (1830-1890). Essa obra, juntamente com outras realizadas no mesmo período do pontificado de Pio IX, perfaz um programa iconológico e um corpus narrativo de fundo artístico e sagrado, que são testemunhos da pedagogia e dos debates políticos na história do catolicismo romano e brasileiro do século XIX. Além disso, movimenta artistas que atuaram sob o mecenato do papa Pio IX para cidades latinoamericanas como Santiago, no Chile, e Belém do Pará, no Brasil, evidenciando conexões artísticas, intelectuais e religiosas entre o Vaticano e a América do Sul, como parte do movimento internacional de renovação do catolicismo.
\end{abstract}

Palavras-chave: D. Macedo Costa, Luca Carimini, Arte italiana, Programa iconológico e Reforma católica.

\begin{abstract}
This article analyses the role of sacred and religious art in Amazonia in the context of the catholic renovation movement of the 19th century, known as Catholic Reform. For that, it takes the order of the main altar of Our Lady of Belém by Pará's Bishop Antônio de Macedo Costa (1830-1891) to Italian architect Luca Carimini (1830-1890) as its study object. This piece, along with others made throughout the period of Pio IX's pontificate, constitutes an iconological programme as well as an artistic and sacred narrative body, which testify to the pedagogical and political debates on the history of Roman Catholicism in Brazil in the 19th century. Besides that, it moves artists that acted under the patronage of Pope Pius IX in Latin American cities such as Santiago, in Chile, and Belém do Pará, in Brazil, putting in evidence the artistic, intellectual and religious connections between the Vatican and South America, as part of an international renewal movement of Catholicism.
\end{abstract}

Keywords: D. Macedo Costa, Luca Carimini, Italian art, Iconological program and Catholical reform.

Artigo recebido em 31 de janeiro de 2016 e aprovado em 08 de julho de 2016.

Agradecemos ao CNPq e ao Programa de intercâmbio Santander, pelo auxílio nas pesquisas em Roma, Lisboa e Belém.

* Doutor em História. Professor da Faculdade de História e do Programa de Pós-graduação em História Social da Amazônia e pesquisador do CNPq. País de origem: Brasil. E-mail: figueiredoaldrin@gmail.com.

** Doutor em História. Professor da Escola de Aplicação da Universidade Federal do Pará. País de origem: Brasil. E-mail: pibosfr@hotmail.com

Horizonte, Belo Horizonte, v. 14, n. 43, p. 975-1011 jul./set. 2016 - ISSN 2175-5841 


\section{Introdução ${ }^{1}$}

Tomando como objeto de análise o campo simbólico e as narrativas em torno da construção do altar-mor da Catedral da Sé do Pará, buscamos aproximar, neste artigo, a história da arte do século XIX com os projetos de reforma na igreja católica brasileira na segunda metade do século XIX. Na defesa da soberania da Igreja diante do processo de secularização, a arte a serviço da religião ao tempo do pontificado de Pio IX exerceria seu papel nos recantos mais longínquos do mundo, ecoando nas margens da baía do Guajará, em Belém do Pará, cujo altar romano foi seu primeiro manifesto. Aqui argumentamos que esse evento foi fundamental na propagação da arte italiana na Amazônia e foi desenvolvido a partir da construção de um programa artístico mais amplo, desenhado com base em narrativas sagradas tomadas a partir de um discurso oficial da Igreja Romana ao tempo de Pio IX. Enfatizamos aqui, portanto, que é exatamente a partir deste momento que desembarcará na capital do Pará o que havia de mais atualizado no ambiente artístico italiano. Roma era como um mito de origem e, ao mesmo tempo, matriz da arte sacra do mundo cristão no ocidente ${ }^{2}$. O altar seria, portanto, o ponto de partida na difusão no Brasil das linguagens artísticas comuns à doutrina da Sé Romana. D. Macedo Costa, por seu turno, seria o idealizador de um programa iconológico para reforma de toda a decoração da catedral, ponto alto de seu episcopado.

Adiantamos que o templo paraense tinha uma vasta história pregressa. A Sé do Pará havia sido a primeira igreja construída de toda a Amazônia brasileira, levantada provisoriamente dentro do Forte do Presépio, em 1616, no ano da fundação de Belém, e dedicada a Nossa Senhora da Graça. Poucos anos depois foi transferida para o atual Largo da Sé, numa modesta construção de taipa de pilão.

\footnotetext{
${ }^{1}$ Este artigo é parte de uma pesquisa mais ampla sobre a circulação e recepção de arte estrangeira em Belém do Pará na segunda metade do século XIX. Os autores agradecem a Vitor Serrão, Giovanna Capittelli, pelas dicas importantes, e a Pedro Teles e aos e editores e pareceristas de Horizonte, pela leitura atenta e comentários críticos à primeira versão do que vai aqui impresso.

${ }^{2}$ Aqui vale destacar a importância de Roma na criação de "arte sacra", destinada à liturgia e do culto do divino, e também da chamada "arte religiosa" que não necessariamente era destinada ao culto litúrgico, mas sim algumas vezes devocional, e que nem sempre trazia os elementos iconológicos definidos pela Igreja Católica. Cf. BOESPFLUG (2008, p.12).
}

Horizonte, Belo Horizonte, v. 14, n. 43, p. 975-1011, jul./set. 2016 - ISSN 2175-5841 
Já no século XVIII, em 1719, quando a Diocese do Maranhão foi desmembrada a pedido de D. João V e a capital do Pará passou a sediar a sua própria diocese, a Matriz ganhou direito e honras de Sé Episcopal (PINTO, 1906, p.25). As obras da atual edificação, construída no mesmo local da primeira igreja seiscentista, tiveram início no ano de 1748. Data dessa época a planta geral da igreja que podemos apreciar nos dias de hoje, além dos níveis inferiores da fachada, incluindo o portal principal, de feição barroca e estilo pombalino. Após algumas interrupções, a direção das obras foi assumida, em 1755, pelo arquiteto bolonhês Giuseppe Antonio Landi (1713-1791), chegado a Belém em 1753, e responsável por grande parte do traço de algumas das mais antigas igrejas da capital do Pará. Landi terminou a fachada, acrescentando as duas torres e o frontão, sendo a construção totalmente concluída em 1782 (DERENJI, 2011). Foi exatamente esse templo, sede do cabido paraense, que D. Macedo Costa tomou para seu projeto de reforma e modernização na década de 1860, com o objetivo de trazer para Belém obras de artistas renomados dos círculos romanos, como também de colocar a antiga Catedral de Belém no mesmo patamar das igrejas reformadas por Pio IX durante seu longo pontificado (RODRIGUES, 2015).

A história deste altar, porém, é muito mais rica. Em novembro de 1871, aportava em Belém do Pará o navio francês Louis \& Anne, trazendo a bordo um altar de mármore destinado a ser colocado na abside da Catedral da Sé do Pará. A imprensa da época, tanto em Belém como no Rio de Janeiro, procurava narrar essa história pelo seu começo. O jornal O Apostólo contava que o bispo do Pará, D. Antônio de Macedo Costa, teria feito uma promessa em seu nome e dos de seus diocesanos a fim de erigir "um grande e belo altar de mármores em honra da Santíssima Virgem Nossa Senhora, Padroeira da diocese”. Como a Catedral era orago de Nossa Senhora da Graça desde os tempos coloniais, o bispo pretendia entregar em cerimônia perpétua a Nossa Senhora de Belém, que a ele teria se revelado em sonho. Para realizar essa obra, D. Macedo aproveitou sua estada em Roma, em 1867, "por ocasião da solene festividade do Centenário dos Bemaventurados Apóstolos S. Pedro e S. Paulo”, e “determinou contratar essa obra com 
o hábil arquiteto e escultor Luca Carimini”. O monumento deveria ser executado "segundo um elegante modelo em relevo" que o bispo teria visto na oficina do artista, "delineado e esculpido" em mármore italiano. Sonho e promessa seriam o início de uma longa empreitada que buscava transformar a antiga catedral num templo moderno nos parâmetros do século XIX, senão "um dos mais formosos templos do Império do Brasil” (BISPADO, 1874, p.2).

Antes, porém de entrar no debate sobre o altar e suas narrativas, é importante refletir sobre quem era o bispo que estava por trás dessa obra. D. Macedo Costa foi um dos mais eminentes prelados do império. Nascido em Maragogipe, na Bahia, em 1830, ingressou no seminário de Salvador em 1848, seguindo depois para França onde deu continuidade aos seus estudos eclesiásticos, entre 1852 e 1854, primeiramente no Seminário de São Celestino, em Bourges, e, posteriormente, entre 1854 a 1857, no Seminário de São Sulpício, em Paris. Lá mesmo, em Paris, ordenou-se presbítero no dia 19 de dezembro de 1857, aos 27 anos, pelas mãos do Cardeal Arcebispo de Paris, François Nicholas Madeleine Morlot (1795-1862). Dois anos depois concluiu seu doutoramento em Direito Canônico pela Pontifícia Universidade Gregoriana, em Roma, no dia 28 de junho de 1859. De volta ao Brasil, foi indicado para o episcopado pelo arcebispo da Bahia e Primaz do Brasil, o paraense Dom Romualdo de Seixas (1787-1860), tendo seu nome sido apresentado pelo Imperador Dom Pedro II à Santa Sé em março de 1860. Ainda em 1860, o Papa Pio IX (1792-1878) confirmou a nomeação do padre doutor Antônio de Macedo Costa como $10^{\circ}$ Bispo do Pará, sendo ordenado como chefe espiritual da diocese paraense no dia 21 de abril de 1861, em solenidade dirigida pelo Internúncio Apostólico no Brasil, Dom Mariano Falcinelli Antoniacci (1806-1874). No mês seguinte, dia 23 de maio, D. Macedo tomou a posse no bispado por procuração, chegando a Belém no dia 24 de julho. Sua entrada solene na catedral paraense deu-se no dia 10 de agosto, dia de São Lourenço, mártir do cristianismo, e fez publicar no mesmo dia de sua entrada sua primeira Carta Pastoral, com data de $1^{\circ}$ de agosto de 1861 (LUSTOSA, 1992; AZZI, 1992; MAUÉS, 1991; 1997; 1997a, MARTINS, 2002; NEVES, 2009). 
Essa trajetória foi apenas o início da carreira de um dos líderes da IgrejaCatólica no Brasil do século XIX e figura proeminente no movimento de reforma do catolicismo brasileiro. Alguns autores chamaram esse movimento de "romanização" associando-o ao ultramontanismo, processo este ocorrido na Europa do século XIX que se apresentava como doutrina católica que buscava o papado ou a Igreja de Roma como sua principal referência política e religiosa (OLIVEIRA, 1976; AZZI, 1976; 1992; BEOZZO, 1977). Diversos autores que escreveram sobre a reforma católica no Pará do século XIX, também corroboram a ideia de que a reforma católica é parte do mesmo processo de "romanização" do catolicismo e que este provém, em parte, do ultramonismo europeu. Tanto é que, autores como MAUES (1997; 1997a) e NEVES (2009), referem-se o prelado paraense como bispo "romanizador" ou agente do "clero ultramontano". Recentemente, COSTA (2016, p.7) referiu-se a D. Macedo Costa como "batalhador incansável da igreja ultramontana”.

De fato, o termo latino ultramontanus, que significava "além das montanhas”, especificamente, para além dos Alpes de quem está em França ou na Alemanha, reforçava e defendia o poder e as prerrogativas do papa em matéria de disciplina e fé. Nomes como Joseph de Maistre (1753-1821), Louis Veuillot (1813-1883), Hughes de Lamennais (1782-1854) e Emmanuel d'Alzon (1810-1880) estiveram entre os mentores intelectuais romanizadores. De um modo geral, esse movimento católico pretendia contrapor-se ao sistema galicanista que, em Paris, como em outras partes do mundo, defendia diferentes versões de regalismo, com uma aproximação maior da Igreja Católica com os estados nacionais, como josefinismo austríaco ou o febronianismo alemão, ou ainda conciliarismo, que subordinava a autoridade do papado ao de um conselho de bispos (OAKLEY, 2003, SANTOS, 1992). Recorde-se, também, no mesmo rastro de ideias, o conteúdo político do Kulturkampf, movimento anticlerical iniciado pelo chanceler Otto von Bismarck (1815-1898), na Alemanha, em 1872 (GROSS, 1997). Pesquisas maisrecentes, no entanto, têm questionado o uso dos termos romanização e ultramontanismo no Brasil, tanto em termos historiográficos como também para 
evidenciar a existência de identidade própria da reforma católica brasileira. Essas novas leituras procuram englobar diferentes contextos e debates internos, assim como os diversos "agentes" sociais do passado brasileiro entre políticos, clérigos e leigos. (SANTIROCHI, 2010; AQUINO, 2013).

\section{O Altar de Luca Carimini nos tempos da reforma católica brasileira}

Dom Macedo Costa, com a obra do novo altar da Catedral de Belém, unia-se ao projeto de Pio IX, que Giovanna Capitelli chamou de "monumentomania" vaticana (2013, p.147). No Brasil, as gazetas do Rio de Janeiro e Belém trataram de destacar os detalhes do "grande feito religioso e artístico". O altar como documento e monumento e, ao mesmo tempo, como lugar de memória eternizaria os feitos do prelado à posteridade. Por isso mesmo, vale a pena acompanhar os termos que o jornal o Apóstolo dá, sobre descrição do altar, passada pelos jargões de arquitetura de Carimini:

A urna do altar tem de levantar-se sobre três degraus de mármores brancos, com frontal embutido de vários esmaltes, e um Tabernáculo esculpido a primor com elegantes colunetas. Por trás do altar e separado dele, ergue-se o grandioso retábulo, começando por um vasto soco, pedestal e cimalha. Sobre estas bases surge a ordem em quatro colunas de alabastro, bases áticas e capiteis coríntios, realçando sobre quatro pilastras também com suas bases e capiteis do mesmo estilo. Os intervalos entre estas pilastras são virtuosamente moldurados de octógonos e hexágonos, correndo em cima uma cimalha com a competente arquitrave, friso e cornija, sobre a qual se levanta a arquivolta, toda entalhada de artesões e molduras, e dominada por nova cimalha, em cuja arquitrave ler-se-á uma inscrição análoga à Virgem Santíssima, cinco estatuas de mármores, uma representação de S. Pedro, outra de S. Paulo, e no cimo Jesus Cristo entre dois anjos adoradores. A altura geral mediria, segundo o contrato, 8 metros e 50 centímetros, mas foi depois elevada e 10 metros e 50 centímetros (BISPADO, 1874, p.2).

De volta a Roma para o Concílio em 1869, D. Macedo Costa teria encontrado o altar quase concluído, “com a perfeição e dimensões convencionadas”. Naocasião, Luca Carimini (1830-1890) havia armado a obra na própria oficina, onde foi "visitada por grande número de artistas romanos e estrangeiros, e por 
muitos Prelados e outras personagens distintas, merecendo geral sufrágio e aprovação", como o bispo mesmo foi testemunha. Nesse evento, até o Sumo Pontífice, nascido Giovanni Maria Mastai-Ferretti, “o magnânimo Pio IX, que se dignara interessar-se sobremaneira por esta obra”, para a qual teria concorrido generosamente, manifestou o "desejo de também visitar o altar da Catedral do Pará”, o que não teria sido possível "infelizmente realizar-se em razão dos tristes acontecimentos que vieram pouco depois sobressaltar e perturbar Roma”. Mas a atenção do papa ao altar não se limitaria a isso. De acordo com a gazeta, “O Santíssimo Padre Pio IX” teria dado "neste negócio muitas delicadíssimas provas de paternal benevolência para com S. Ex. ${ }^{a}$ Rev. ${ }^{a}$ e a diocese do Pará”. Tais fatos não poderiam passar em branco nessa história, devido à sua importância “e cuja recordação é o que dará mais valor ao piedoso monumento que a devoção do povo quis erguer em honra de sua Imaculada Padroeira” (BISPADO, 1874, p.2). E assim continua a narrativa, enfatizando os passos dados pelo bispo na aquisição da obra:

Em uma audiência que teve do Santíssimo Padre, falando-lhe S. Ex. ${ }^{a}$ da obra do altar que tinha já encomendada, mostrou quanto seria feliz (e seus diocesanos) se S. Santidade se dignasse a ela cooperar dando os mármores precisos; e acrescentou S. Ex. ${ }^{\text {a }}$ que lhe parecia muito justo que o nome de Sua Santidade, como o do primeiro servo de Maria neste século, ficasse para sempre ligado a uma obra que toda tinha por fim a honra e a glória da Santíssima Virgem. Respondeu Sua Santidade com aquela sua nobre singeleza e benignidade, que nisso leva todo, mas que não sabia se haveria mármores disponíveis: "Se houver, acrescentou, tê-los-á o Bispo." Passaram-se muitos dias, sem que nada transpirasse. Não era possível que acabrunhado pelas fadigas das grandes festas do Centenário, das audiências que era preciso dar ao Episcopado Católico reunido então em Roma, não falando de uma alusão de outros graves negócios, houvesse o Santo Padre esquecido o pedido do humilde Bispo do Pará? Para sondar em que altura estavam as cousas, resolveu S. Ex. ${ }^{a}$ ir com o Ex. ${ }^{0} \mathrm{Sr}$. ministro Brasileiro à casa do Ex. ${ }^{\circ}$ Sr. ministro do comércio e das artes, e saber dele se tinha recebido alguma ordem do Santo Padre a respeito dos mármores. Acolheu-os este cavalheiro com nobreza e simplicidade toda romana, e declarou-lhes que indo na véspera mesmo conferenciar com sua Santidade sobre uma multidão de graves negócios do Estado, havia muitos dias empatados, depois de concluída uma larga audiência de mais de duas horas, e estando o Santo Pontífice visivelmente fatigado, lhe falara ele ministro desses mármores, dizendo que desejava que o Bispo do Pará fosse satisfeito. Este desejo do Santo Padre é uma ordem para mim, continuou o ministro; e declarou que punha à disposição do arquiteto Luca Carimini todos os mármores necessários. Como, porém, sobreviesse a invasão de Roma antes da total entrega desses mármores, e se tornasse essa indisponível depois daquele acontecimento, dignou-se o Santo Padre,

Horizonte, Belo Horizonte, v. 14, n. 43, p. 975-1011, jul./set. 2016 - ISSN 2175-5841 
como em compensação, ofertar para a obra do altar a soma de 1,500 escudos, mais de 3:00o\$ooo da nossa moeda (BISPADO, 1874, p.2).

Por meio dessas contribuições ficaria "a memória da magnanimidade e magnificência do grande e imortal Pontífice Pio IX", um dos "maiores vultos que os vindouros" admirariam "entre os Vigários de Cristo", sublinha a gazeta, "ligada para sempre a esta obra do Altar de Maria Santíssima que se tem de erigir na Igreja Catedral desta cidade de Belém" (BISPADO, 1874, p.2). A relação de D. Macedo Costa com Pio IX e a cúria romana é um capítulo à parte no catolicismo brasileiro do século XIX. Recorde-se também que, além de uma das principais lideranças do clero católico nacional, D. Macedo Costa já havia feito ampla defesa do poder temporal do mesmo Pio IX, em um opúsculo publicado em Lisboa, em 1861, sob o título Pio IX, pontífice e rei (COSTA, 1861). Na década de 1870, como bem documentou o padre e historiador italiano Giacomo Martina, por meio de correspondências trocadas entre o papa e o bispo paraense, um dos alvos mais importantes da política eclesiástica foi a maçonaria (1990, p.446-450). A contenda era antiga, cheia de detalhes e ramificações, porém o tópico da luta entre liberais e conservadores, entre livre pensadores e católicos, estava na ordem do dia.

Em 1874, o mesmo jornal $O$ Apóstolo, ainda tratando dos gastos com a reforma da catedral de Belém, saía em defesa da reputação e honestidade de D. Macedo Costa, atacadas pela imprensa opositora no clima tenso do momento. Com efeito, publicou-se um minucioso balanço do custo geral da obra, que chegaria a 52:766\$916 (cinquenta e dois contos, setecentos e sessenta e seis mil e novecentos e dezesseis réis). Nesse montante estariam incluídos "a mão de obra, custo de uma parte do mármore, de um quadro e de cinco estatuas", somando a quantia de 45:206\$663 (quarenta e cinco contos, duzentos e seis mil e seiscentos e sessenta e três réis); assim como as despesas de "encaixotamento, seguro, transporte e etc.", no valor de 7:560\$253 (sete contos, quinhentos e sessenta mil e duzentos e cinquenta e três réis). Também constavam as contribuições específicas dadas por cada instituição e personalidades envolvidas na encomenda do altar. Teriam concorrido para a obra o governo imperial, com a soma de 20:000\$0oo (vinte 
contos de réis); a província, com 12:000\$000 (doze contos de réis); o próprio bispo, com 1:600\$ooo (um conto e seiscentos mil réis); os seus diocesanos, com 4:831\$100 (quatro contos, oitocentos e trinta e um mil e cem réis). Além deles, aparece o Imperador D. Pedro II, que teria se dignado "também oferecer de seu bolsinho" a soma de 1:00o $\$ 300$ (um conto e trezentos réis) e o sumo pontífice Pio IX, com a doação em mármore e dinheiro de 6:122\$690 (seis contos, cento e vinte dois mil e seiscentos e noventa réis). Todo esse dinheiro montava a soma de 55:075\$556 (cinquenta e cinco contos, setenta e cinco mil e quinhentos e cinquenta e seis réis), havendo ainda um déficit de 10:121\$766 (dez contos, cento e vinte e um mil e setecentos e sessenta e seis réis) sobre a receita, devidamente documentado (BISPADO, 1874, p.2).

\section{A decoração da Catedral da Sé do Pará no século XIX: memorialística e historiografia da arte}

Neste ponto há que se fazer uma digressão sobre a memória da Catedral da Sé e as "repetições" que a historiografia da arte irá fazer dessa reforma decorativa do século XIX. Toda essa história que já descrevemos da construção do altar foi reproduzida na íntegra pelo memorialista católico, monsenhor Américo Leal, em seu livro "A Igreja da Sé” (LEAL, 1979, p.48). O escritor foi tão fiel ao que noticiara o jornal $O$ Apóstolo que a primeira impressão que se tem é de que o texto seja fruto de seu próprio punho, já que não menciona a fonte de onde transcreveu. Assim, a versão dos acontecimentos que ofereceu é exatamente aquela que o bispo apresentou na gazeta católica da época. Algo como a voz da Igreja. Sobressai a promessa de levantar o altar em honra à padroeira dos paraenses, seguida do apurado senso estético do prelado na condução da decoração da Catedral da Sé. Desse tipo de interpretação também comunga D. Antônio Lustosa (1886-1974), que percebeu em D. Macedo Costa um homem dedicado à cultura letrada e às belas 
artes ${ }^{3}$. Trata-se, portanto, da qualidade fundamental que impulsionara o prelado rumo ao projeto de "aformoseamento da catedral". O bispo teria visto, "no grande templo de belas linhas arquitetônicas, a possibilidade de uma reforma, que o havia de tornar um dos mais belos do Brasil” (LUSTOSA, 1992, p.514). Argumento repetido e reiterado por pesquisas recentes, como a de Renata Maués (MAUÉS, 2011). Sem negar o "bom gosto" de D. Macedo Costa, cabe dizer que esse tipo de julgamento é muito superficial para se entender as motivações que levaram à encomenda do altar e, em consequência, à decoração do edifício. Além do mais, é preciso não perder de vista que "o gosto é um filtro com implicações morais e cognitivas, além das estéticas" (GINZBURG, 2007, p.69).

Basta recorrermos novamente ao que diz $O$ Apóstolo e logo percebemos elementos que nos lançam da esfera individual do bispo ao contexto mais amplo da ambiciosa política cultural de Pio IX. Explícito ou implícito, sem dúvida, está tudo ali entre 1869 e 1870: o Concílio do Vaticano I e as cerimônias dos centésimo oitavo aniversário dos mártires de São Pedro e São Paulo; o momento de inauguração da Galleria dei Santi e dei Beati (CAPITELLI, 2008) e a Esposizione romana delle opere di ogni arte eseguite pel culto cattolico (L'ESPOSIZIONE ROMANA, 1870); a encomenda feita a um dos principais artistas da Accademia di San Luca protegido de Mastai; o interesse e a participação direta do papa no financiamento do altar; as tropas do exército sardo-piemontês às portas de Roma e a tomada da cidade eterna, impedindo a visita do pontífice à obra; um imponente "altar de mármore" sinalizando novas tendências estéticas determinadas a substituir o modelo colonial pela sobriedade clássica romana; por fim, os cultos promovidos por Pio IX, como o da Imaculada Conceição, promulgado em 18 de dezembro de 1854, sob o invólucro da "Santíssima Virgem", e do Sagrado Coração de Jesus, figurado na estátua de “Jesus Cristo entre dois anjos adoradores”.

\footnotetext{
${ }^{3}$ D. Antônio de Almeida Lustosa foi bispo do Pará entre 1931 e 1941. Nos dez anos de seu episcopado, visitou todo o território da arquidiocese, apesar das grandes dificuldades de acesso e excessiva extensão territorial. A partir de setembro de 1932, Dom Lustosa passou a publicar no periódico católico $A$ Palavra, suas crônicas relativas às visitas pastorais. Esta coluna terá o nome de $A$ Margem da Visita Pastoral, posteriormente publicada em livro. Entre suas obras se destaca uma biografia de Dom Macedo Costa, referida neste artigo (LUSTOSA, 1992).
} 
Desse modo, por meio de D. Macedo Costa, a Amazônia entrou nas estratégias da pedagogia artística e do programa iconológico e sacro traçados em Roma, tornando-se um dos seus incentivadores e divulgadores na América do Sul. Dentro do mesmo processo, talvez o caso mais próximo de Belém do Pará seja o de Santiago do Chile. Esse país teceu relações frutíferas com Roma no campo artístico, especialmente a partir de 1846, quando subiu ao trono o pontífice Pio IX. Na verdade, antes mesmo disso tudo começar, o Chile já era um país familiar ao papa. Aos seus trinta e dois anos, quando estava apenas no princípio de sua célebre carreira eclesiástica, Mastai fez parte da primeira legação pontifícia que colocou os pés na América Latina, a chamada “Legação Muzi”, organizada por Pio VII. A etapa chilena dessa viagem foi registrada em seu próprio diário e representou uma das raras experiências que marcariam e orientariam sucessivamente a política do futuro pontífice no exterior, especialmente atenta aos problemas e demandas provenientes da América Latina. Em 1824, Mastai passou seis meses em um antigo e austero convento da Recoleta Dominica, em Santiago. Durante sua estada teve ocasião de conhecer numerosos eclesiásticos e estabelecer também relações com alguns expoentes da intelectualidade chilena, firmando uma série de contatos que não deixaria de fomentar ao longo do tempo. Nos anos de seu governo pastoral, Pio IX enviou algumas doações à catedral da cidade: um precioso relicário e próprio retrato pintado por Vincenzo Podesti (1812-1897), irmão de Francesco Podesti (1800-1895). A relação afetiva do papa com o Chile seria lembrada até mesmo no seu próprio testamento, no momento de sua morte, em 1878 (CAPITELLI, 2010, p.46; SERAFINI, 1958; THORNTON, 1955).

É no curso de seu pontificado que ocorre o episódio da construção e, especialmente, da decoração da nova igreja de Recoleta Dominica em Santiago na segunda metade do século XIX. Na realização está a ligação do papa com esse país, mas também a sua intensa e apaixonada atividade em apoio às artes e aos artistas, uma atividade, é bom lembrar, de caráter antimoderno, tradicionalista, propagandista, cultivada sobretudo em Roma, porém destinada a condicionar uma 
parte considerável da arte sacra no mundo católico. A exemplo do que ocorrerá na Catedral de Belém, é ao contexto romano que se dirige a inciativa chilena em busca de modelos e artífices. Na intermediação da operação esteve o padre dominicano Juan Andrea O’Brien, residente em Roma na época. Sua história se entrecruza com a do monsenhor Giovanni Muzi (1772-1849), protagonista da primeira legação pontifícia na América Latina, o qual, ao regressar da Cittá di Castello em 1827, o havia ordenado sacerdote, mas também está ligada indiretamente com a do jovem Mastai Ferretti, que exatamente nessa época se convertia em bispo de Spoleto. Segundo Capitelli, o padre O’Brien teve um papel fundamental na construção da nova igreja da Recoleta Dominica. Teria sido ele, por exemplo, a sugerir como modelo para a nova construção chilena a basílica romana de S. Paulo fora dos Muros. É intrigante como surge a ideia de construção da nova igreja. Tudo teria começado quanto o próprio padre O’Brien encomendou em Roma ao escultor piemontês Antonio Basetti a estátua da Madonna del Rosario para o altar-mor da antiga Igreja da Recoleta Dominica. Esse seria o ponto de partida nas relações artísticas entre a cidade eterna e Santiago do Chile. A recepção à estátua em Santiago foi tão positiva que se decidiu contratar um arquiteto para construir um novo altar apto a abrigar a imagem. Foi então que, em 1853, o padre O’Brein entrou em contato com Eusebio Chelli (1820-1895), arquiteto italiano formado pela Accademia di San Luca. O altar resultou tão imponente aos olhos dos dominicanos chilenos que os convenceu a mandar construir uma nova igreja que pudesse dar-lhe um melhor lugar. Na construção da nova Igreja da Recoleta Dominica foi contratado o mesmo Eusebio Chelli que, um ano depois de concluir a obra, começou a pensar na sua decoração pictórica (CAPITELLI, 2010, p.47-8).

A responsabilidade assumida por Chelli em Santiago reproduzia uma prática habitual em Roma, posta novamente em vigor por Pio IX, na qual os encargos de grandes ciclos decorativos se dividiam entre vários artistas e cabia ao arquiteto controlar sua execução. Explicitamos esse projeto, pois o mesmo, juntamente com seus artistas executores, é bastante análogo ao desenvolvido posteriormente na Catedral do Pará. Em Santiago, a decoração da nova igreja chilena era imponente, 
contando com nada menos que catorze grandes telas saídas de Roma em direção a Santiago, sendo que algumas chegam em 1870, um ano antes do altar da Sé de Belém. Os pintores implicados na decoração pertenciam a distintas gerações, porém todos podiam considerar-se do agrado de Pio IX, sendo que alguns deles também farão obras de arte para Belém (RODRIGUES, 2015). Francesco Coghetti (1801-1875) e Pietro Gagliardi (1809-1890), os mais velhos, estavam entre os artistas mais ativos e apreciados no campo da pintura sacra em Roma, com numerosos quadros destinados não só às capelas da cidade eterna, mas também a templos no exterior. Juntos a eles estavam os mais jovens Cesare Mariani (18261901), Roberto Bompiani (1821-1908), Francesco Grandi (1831-1891), Giuseppe Sereni (1823-1928) e Casimiro Brugnone De Rossi (1818-1876). Eles tinham feito parte de uma esquadra selecionada por Tommaso Minardi (1787-1871) para a decoração em afresco do ático da nave central da Basílica Ostiense em Roma. Somava-se ao grupo o já referido Vincenzo Podesti, responsável por importantes projetos decorativos, encomendados sob o mecenato de Pio IX, para Sala da Imaculada Conceição nos Palácios Vaticanos. Enfim, oito dos onze pintores implicados no projeto da Igreja da Recoleta Dominica tinham participado em distintos níveis na decoração da Basílica de São Paulo Extramuros. Participaram ainda da decoração os menos famosos Enrico Bartolomei (1818-1901) e o jovem Guido Guidi (CAPITELLI, 2010, p.51-2).

Com essa obra, inicia-se um fluxo de arte romana em direção ao Chile. Pinturas, esculturas, altares de mármore chegam às igrejas, assim como se constrói um considerável número de edifícios eclesiásticos e civis concebidos por Eusebio Chelli. Este caminho se repete também em outras regiões da América Latina, claramente observável no caso do Pará. Mas as semelhanças entre o contexto chileno e o ambiente amazônico não param por aí. O historiador Fernando Guzmán, que estudou a questão dos altares chilenos, tenta desvelar algumas das razões que poderiam explicar o sucesso da arte romana em um país cuja elite social, como em toda a América Latina, tinha Paris como modelo de cultura e modernidade. Embora o país tenha passado pelo processo de romanização da 
Igreja, o historiador sublinha que a vida eclesiástica chilena foi marcada, durante a segunda metade do século XIX, pela presença religiosa francesa, dado suficiente para se adotar a arte sacra produzida na França. Todavia, não foi isso que aconteceu ali. Segundo suas pesquisas, a arte romana não só dominou a estética religiosa como também desempenhou papel de grande importância na representação da identidade nacional ou, citando Benedict Anderson, na consolidação de uma comunidade imaginada (ANDERSON, 1993, p.23). As suas características formais podem ser consideradas como extremamente funcionais para a construção de uma nova Igreja Católica que fosse coerente com o progresso republicano do Chile. A regeneração da nação, expressão usada pelos intelectuais e políticos chilenos da primeira metade do século XIX para se referirem ao processo de Independência, pressupunha, junto a muitos outros aspectos, a libertação do país do domínio da monarquia espanhola e a atualização da Igreja aos novos tempos. Nesse sentido, a arte religiosa romana oferecia um conjunto de soluções arquitetônicas e plásticas que, para muitos, representava o que a Igreja deveria ser no Chile. A elite então seria capaz de traçar, ao menos neste âmbito, um projeto e torná-lo explícito por meio de imagens eficazes e estimulantes (GUZMÁN, 2012, p.420).

Dentro do projeto de construção nacional formulado nos mais altos círculos políticos e intelectuais do país, afirma Guzmán, a oligarquia chilena estava consciente da necessidade de incluir o povo em seu programa civilizatório, tendo como primeiro passo, inculcar a ideia de que o passado colonial era um obstáculo ao progresso da nação. Para isso, governantes, intelectuais e clérigos, em grande parte, compartilhavam dessa visão. Foi nesse tempo que a hierarquia da Igreja chilena passou a considerar negativa certas práticas votivas de origem colonial, expressas principalmente na religiosidade popular. Essas manifestações, que incluíam a arte sacra tradicional, foram então vistas como arcaicas, ultrapassadas e incivilizadas. Era necessária como que uma “depuração” dessas práticas exteriores do catolicismo. Segue-se que a primeira metade do século XIX foi caracterizada pela persistência das soluções formais do barroco hispano-americano. A maioria 
dos artistas continuava a pintar e esculpir as próprias obras à maneira do século XVIII, portanto o aspecto das igrejas chilenas ainda era dominado pelos altares de notável "fantasia ornamental", com douramento ou imitação de mármore e estruturas que podiam hospedar dezenas de esculturas e pinturas. Identificados como resíduos de uma herança colonial agora contestada, essa antiga decoração foi o principal alvo da elite, que passou a manifestar desprezo por essas formas pretéritas, consideradas "aberrações do bom gosto". Sem artistas locais que atendessem aos seus anseios de renovação, o clero chileno voltou-se para Roma (GUZMÁN, 2012, p.420-1).

Vale lembrar que isso ocorre num momento favorável do país. Gozando de uma longa estabilidade política durante a segunda metade do século XIX, o Chile pôde financiar a importação de arte europeia em grande escala, na qual estavam incluídos os altares de mármore produzidos em Roma. De fato, algo similar ocorre em Belém, com o incremento da produção e exportação da borracha, a partir da década de 1870, com a província e depois do Estado como agente patrocinador da arte na capital do Pará (SARGES, 2000). O impacto dessas obras na sociedade chilena não passou despercebido. Os altares romanos sobressaiam tanto por suas dimensões, que superavam amplamente qualquer altar produzido até aquele momento, quanto pelas suas qualidades estéticas: a leveza, a luminosidade, as diferenças de cor e tantas outras riquezas dos materiais que os chilenos não se cansavam de admirar. $\mathrm{Na}$ sua estrutura, esses altares apresentavam várias novidades arquitetônicas que estavam em perfeita sintonia com as inclinações estéticas das elites. Segundo Guzmán, durante a segunda metade do século XIX os últimos "horrores" da teatralidade barroca sucumbiram diante da simplicidade acadêmica dos modelos romanos. Assim, as velhas formas da arte religiosa, e com ela as antigas formas de devoção, tornaram-se periféricas. Inventa-se uma tradição (GUZMÁN, 2012, p.425-8). Enfim, a arte anti-moderna e tradicionalista proposta por Pio IX foi para a elite chilena o modelo que permitiu criar uma nova arte católica nacional. 


\section{Carimini e a galeria vaticana em Belém do Pará: programa iconológico e narrativa sagrada na arte}

Contemporaneamente ao Chile, no Pará desenvolvia-se uma política com muita similaridade. Em pleno movimento de reforma católica, D. Macedo não hesitaria em recorrer a artistas italianos ligados à política de Pio IX para dar um novo programa artístico e decorativo à Catedral da Sé de Belém. Suas viagens a Roma na década de 1860 para participar dos principais eventos que redefiniam a atuação da Igreja na sociedade serviram para atualizar a arte sacra paraense dentro dos princípios defendidos pelo pontífice. Se o Chile tinha um arquiteto como Eusebio Chelli, o norte do Brasil contou com Luca Carimini, que projetou o altar da Catedral de Belém quase ao mesmo tempo em que trabalha na decoração da Igreja de Santa Maria de Loreto (1867-1873), em Roma (GUIA, 2002, p.270). A biografia do escultor daria os passos de seu sucesso nos círculos eclesiásticos de Roma, Santiago e Belém. Nascido em Roma em 1830, Carimini era filho de Pasquale e Lucia Bellucci, artesãos provenientes de Urbisaglia. Depois da morte do pai, em 1844, começou a trabalhar numa oficina de mármores. Em 1846, por sua habilidade, foi chamado para auxiliar Pietro Romaggi, conhecido então como um dos melhores marmoristas romanos. Ali executou lápides e capelas funerárias. Após esse aprendizado, por volta de 1850, ajudado pelo tio materno Baldassarre Bellucci, abriu sua própria oficina, chegando a ter mais de sessenta alunos e aprendizes. Os trabalhos executados foram principalmente monumentos e capelas funerárias, assim como obras de esculturas para o interior de igrejas e altares (PRIORI \& TABARRINI, 1993, p. 29).

Mostras expressivas da atuação de Carimini no âmbito da arte funerária estão no cemitério de Campo di Verano, em Roma. Como outros refinados herdeiros da grande escola artística italiana da segunda metade do século XIX empregados na recuperação de estilos e técnicas do passado, Luca Carimini foi autor de numerosas capelas e tumbas nesse local. Ao mesmo tempo em que desenvolveu essa atividade, frequentou esporadicamente os cursos de escultura e 
pintura da Accademia de San Luca. Em 1851, participou do concurso da academia, ganhando o $2^{\mathrm{o}}$ prêmio pelo ensaio de ornato e um louvor pelo ensaio de arquitetura elementar. Esse momento de intensa atividade se deu sob a direção de reconhecidos professores, como Gaetano Morichini, arquiteto do Apostolato Cattolico. Em 1868, o Archiginnasio em Sapienza o reconheceu arquiteto em seguida à assinatura da comissão de exames da Accademia di San Luca. Por volta de 1876, tornou-se arquiteto dos Pii Stabilimenti di Francia a Roma. Foi exatamente neste ano que começa a estreitar laços com o Brasil, ao se tornar membro correspondente da Academia Imperial de Belas Artes. 4 Com o início da atividade de arquiteto representado na decoração geral do interior da igreja S. Salvatore in Onda, em Roma (1867-78), Carimini consolidou sua fama de acurado construtor, trabalhando não só na Itália, mas também no exterior, sobretudo na América do Sul. No Brasil, executa o projeto arquitetônico da igreja de Nossa Senhora da Penha em Recife, o altar-mor da Catedral de Belém e o púlpito da Catedral de São Paulo. No Chile, executa o altar monumental para a igreja de S. Francisco em Santiago. Durante esse tempo, cercou-se de amigos e parentes que colaboram como assistentes, decoradores, marmoristas: o irmão Davide; o amigo Domenico D’Amico, que dividirá a casa com ele em Via Nazionale; o filho primogênito Merico, que substituiu o pai na direção da oficina artesanal na Via $S$. Giovanni, em Lauretano. A fortuna profissional da década de 1880, que o viu atuar na direção de muitos canteiros, foi interrompida com a morte, em dezembro de 1890.5

\footnotetext{
${ }^{4}$ Luca Carimini (1830-1890) aparece como membro correspondente da Academia Imperial de Belas Artes na Itália numa lista de artistas que vai de 1851 a 1888 (DAZZI, 2006).

${ }^{5}$ Sobre algumas das principais obras executadas por Luca Carimini, temos o seguinte: 1856, restauro interno e decoração na igreja de Santa Maria em Aquiro, Roma; 1858, executa obras Capela do Crucifixo na Basílica dos Santos Apóstolos, Roma; 1867-1873, realiza o seu primeiro trabalho como arquiteto reconhecido: o restauro da "Igreja dos Padeiros", Santa Maria de Loreto no Fórum de Trajano, com a reconstrução da sacristia; 1867-1878, retoma obras na Basílica dos Santos Apóstolos; 1873-1879, executa trabalhos de reconstrução e obras na Igreja de São Salvador em Onda, Roma; 1877-1888, trabalha na igreja de Santo Ivo de Bretoni, Roma; 1879, atua na reconstrução da igreja quatrocentista de Nossa Senhora do Sagrado Coração junto à Piazza Navona, antes chamada de San Giacomo degli Spagnoli; 1883-1890, executa a reconstrução da fachada da igreja de Santa Clara e do Pontifício Colégio Francês na praça Santa Clara; 1884-1888, intervém na igreja e no convento de S. Antonio, na via Merulana; e, em 1888, executa obras no Pontifício colégio Canadense, na via de S. Vitale. (PRIORI \& TABARRINI, 1993, p. 29).
}

Horizonte, Belo Horizonte, v. 14, n. 43, p. 975-1011, jul./set. 2016 - ISSN 2175-5841 
Todo esse movimento artístico italiano do século XIX ainda é pouco estudado, levando-se em conta as fases clássicas, reconhecidas e mais divulgadas do passado italiano. Giulio Carlo Argan, nos três volumes de sua História da Arte Italiana dedica poucas páginas ao século XIX e poucas ao século XX. Com este autor temos pouca ou nenhuma incursão pela política, com uma leitura conservadora, classificatória e cultora da arte tradicional consagrada pelo humanismo e renascimento (ARGAN, 2003, v.3). No entanto, autores importantes como Enrico Castelnuovo, Daniela Vasta, Giovanna Capitelli, entre outros, trouxeram importantes reflexões sobre o século XIX, o universo artístico do risorgimento e da unificação italiana, das conexões internacionais da arte italiana na Europa e na América Latina e da história e trajetória de muitos artistas do período, entre eles, praticamente todos citados neste artigo, a começar por Luca Carimini e Silverio Capparoni (CASTELNUOVO, 1985; 1991; CAPITELLI, 2008, 2010; 2013; VASTA, 2012). Do mesmo modo, apesar da forte influência italiana na arte e na arquitetura de Belém do Pará no século XIX, os estudos ainda enfatizam muito uma pretensa influência francesa, que de fato está mais no campo das letras e dos discursos políticos e ideológicos que na obra cotidiana de artistas, desenhistas e arquitetos. As coleções museológicas belenenses, as igrejas e residências particulares são o melhor testemunho disso (FIGUEIREDO, 2012; 2013). Isso explica, em grande medida, o desconhecimento do espaço profundo de toda essa história, cujo o altar construído para a Catedral de Belém é um bom testemunho.

O altar de mármore feito por Carimini, com seus emblemas narrativos de uma teologia reformada, ainda era um tipo de monumento desconhecido na Amazônia. Desde sua chegada em 1871 aguçou a curiosidade do público paraense, que o veria erguido somente no início da década de 1880. Trata-se de uma obra feita com o emprego de fino mármore de Carrara, em diferentes tonalidades e cortes que lhe dão destacada suntuosidade. Um jornal da época chegou a enfatizar 
o clima de encanto dos fiéis: "Tudo ali causou aos olhos do público da época um verdadeiro encantamento: a simetria e as proporções da forma, o brilho e a correção de cada uma das peças do conjunto foram objetos dos mais efusivos elogios"6. O momento era de claro enlace entre arte e poder religioso. Assim como outros arquitetos de seu tempo, Carimini trabalha no ambicioso projeto iconográfico de Pio IX, dando forma às suas simbologias mais determinantes. Quando D. Macedo encomenda o altar-mor da Catedral de Belém, o artista está totalmente imerso no processo de construção e restauro de templos em Roma sob a autoridade do papa. Neste âmbito se encontra, por exemplo, a intervenção feita na Basílica dos Santos Apóstolos, voltada não só à decoração, mas, sobretudo, à reconfiguração arquitetônica da capela consagrada ao Crucifixo, à direita do presbitério. Essa capela foi completamente restaurada por Carimini, em 1875, que a transformou numa pequena basílica em três naves, reutilizando as mesmas rochas antigas e enriquecendo-a com mármores coloridos. As intervenções que comportavam a realização de novas capelas através de complexos processos formativos, tanto arquitetônicos quanto decorativos, são os indicativos do gosto e da têmpera cultural daquele momento. Ao lado de destacados arquitetos da Roma de Pio IX, como Virginio Vespignani (1808-1882), Andrea Busiri Vici (1818-1911), Carimini trabalha incansavelmente nesse campo com projetos que tentam sempre melhorar a obra do passado (TURCO, 2007, p.111-2).

\footnotetext{
${ }^{6} \mathrm{~A}$ imprensa de um modo geral acompanhou em detalhe a construção do altar da Catedral. Referimo-nos a uma matéria, em especial, que detalha o impacto do monumento religioso entre os fiéis paraenses. Cf. ALTAR DE MÁRMORE (1880, p.1).
} 


\section{Figura 1: Visão parcial do altar-mor da Catedral da Sé de Belém.}

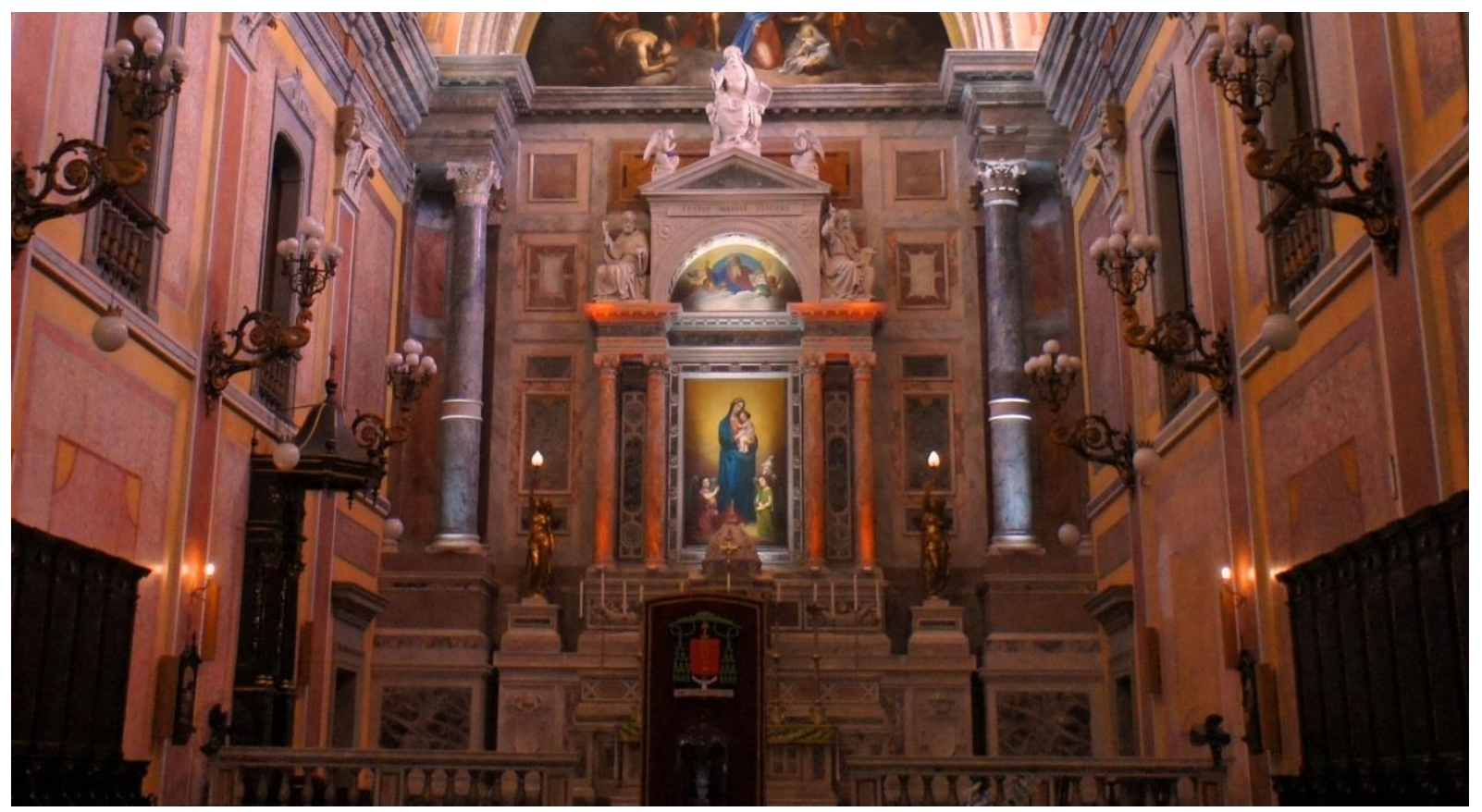

Fonte: Fotografia Silvio Rodrigues, 2015.

Assim, sob o verniz do mecenato pontifício desvela-se uma declarada propaganda do reformismo católico. Na cidade eterna, o pontificado de Pio IX mostra o seu forte clamor religioso no interesse de fazer ressaltar os valores imutáveis e inalteráveis da fé cristã, seja através dos atos religiosos e políticos, seja através de um processo de “cristianização" ulterior de Roma (CONSOLI \& PASQUALI, 2005, p.250). Desse modo, as obras produzidas pelos artistas ligados à Santa Sé traduzem, em grande medida, os princípios assinalados na proclamação do dogma da Imaculada Conceição (8 de dezembro de 1854), por meio de uma profunda interface artística do culto mariano, cujo altar compõe um signo de linguagem e narrativa visual; no Syllabus (1864), com o retorno aos componentes tradicionais da iconologia crista, que analisaremos mais à frente quando tratarmos individualmente das pinturas e esculturas do altar e, enfim, no Concílio Vaticano I (1869-1870), com os fundamentos artísticos de um programa iconológico em diálogo com as constituições dogmáticas Dei Filius, sobre a Fé católica, e Pastor 
Aeternus, sobre o primado e infalibilidade do Papa, quando se pronuncia excathedra, em assuntos de fé e de moral. Mais à frente trataremos desses elementos na análise dos símbolos pessoais de D. Macedo Costa e do papa Pio IX no altar da Sé de Belém. Todos esses momentos, embora distintos na história da Igreja, estão ligados ao mesmo movimento de reforma da Igreja Romana. Esta campanha, digase de passagem, destinada a afirmar, perante os indivíduos e a sociedade, os valores sobrenaturais da religião e a reforçar a autoridade pontifícia e dos prelados em resposta aos desafios do mundo contemporâneo7. Fala-se de um papa onipotente, chefe absoluto da Igreja em todas as instâncias, cuja proclamação da infalibilidade pontifícia viera confirmar. O sucessor do apóstolo Pedro, considerado fundador da Igreja, voltava-se então contra os ditos “males modernos”.

No altar-mor da Catedral de Belém, Carimini, atendendo aos pedidos de Dom Macedo, faz uma espécie de síntese desses momentos-chave. A suntuosidade estética do monumento se une ao discurso moralizante da romanização. De um e de outro lado do sacrário, delicados anjos fundidos em bronze seguram grandes archotes. No centro do altar, a tela Nossa Senhora de Belém, do suíço Melchior Paul von Deschwander (1811-1881), no mesmo estilo purista do traço escultórico de Carimini, alude à padroeira dos belenenses e à devoção mariana, ponto fulcral na teologia ultramontana.

A fortuna crítica, histórica e literária em torno do culto à Nossa Senhora de Belém no Pará é imensa. Tratadistas, cronistas, memorialistas, historiadores, hagiógrafos, clérigos, missionários, estrangeiros e brasileiros, tanto nas épocas colonial, imperial ou republicana, trataram de noticiar a antiguidade e a importância do repertório sacro e histórico que envolveu essa devoção. Alguns, como Manuel Barata, inclusive corrigiram o erro de citar Santa Maria de Belém ao invés de Nossa Senhora de Belém como a invocação dedicada por Francisco Caldeira Castelo Branco no ato de fundação da capital do Pará, em janeiro de 1616

\footnotetext{
${ }^{7}$ Vasta bibliografia existe sobre a atuação de D. Macedo Costa na diocese paraense, no longo episcopado de três décadas e suas conexões com os movimentos de reforma da Igreja Católica nacional e internacionalmente. Sobre seu episcopado recomendamos a leitura de MAUÉS (1987, 1997; 1997a); MARTINS (2001; 2002; 2005) e NEVES (2009).
}

Horizonte, Belo Horizonte, v. 14, n. 43, p. 975-1011, jul./set. 2016 - ISSN 2175-5841 
(BARATA, 1931, p.231). Outros, em tempos diferentes, como o padre João Felipe Bettendorf, o historiador Sebastião da Rocha Pitta, ou o diplomata José Maria da Silva Paranhos Júnior, barão do Rio Branco, identificaram o assento da cidade à toponímia sacra de Nossa Senhora de Belém (BETTENDORF, 1910, p. 45, PITTA, 1976, p.48; RIO BRANCO, 2012, p.613.). Além das muitas referências históricas e religiosas, era importante para D. Macedo Costa reafirmar a devoção à Nossa Senhora de Belém, sob as bênçãos da cúria, em vista da enorme propagação e até suplantação da devoção popular à Nossa Senhora de Nazaré, que de fato já era imensamente maior do que a da antiga padroeira, que na década de 1870 havia se constituído na chamada questão nazarena, dada sua dimensão política e religiosa ${ }^{8}$.

No interior do arco pleno, logo abaixo do frontão, a tela denominada Pai Eterno, de Silverio Capparoni (1831-1907), traz uma representação de Deus entre as nuvens do céu, cercado por cinco querubins, numa das representações clássicas da hierofania cósmica do Criador (ELIADE, 2002, p.59). Os pequenos anjos trazem um significado que retoma a própria tradição da pintura ocidental. Primeiramente, porque os querubins foram pintados como anjos que faziam parte da hierarquia celeste, portanto obras dos domínios de Deus. Numa visão mais moderna, em parte oriunda do judaísmo, esses querubins eram seres em forma de crianças aladas que estavam sobre o Propiciatório da Arca da Aliança. Deve-se reiterar, no entanto, que este ponto de vista anacrônico em relação a estes seres, certamente se deve à iconografia sacra do Renascimento, já que, como há muito havia referido o historiador e apologista judaico-romano Flavius Josephus, a representação dos querubins tinha sido esquecida desde o século I d.C. (JOSEPHUS, 1998, p.146). Além disso, o bispo do Pará D. Macedo Costa defendia a presença dos “anjos meninos" como elemento importante da pedagogia bíblica e, portanto, necessária à disseminação da arte sacra (COSTA, 1894, p.275-6), seguindo o Syllabus de 1864, que enfatizava exatamente, como já anunciamos neste artigo, esse retorno aos

\footnotetext{
${ }^{8}$ Devido o escopo do trabalho e seu foco no campo artístico, não há espaço para uma análise mais detida das dimensões sociais da atuação de D. Macedo Costa na diocese do Pará e sobre os conflitos relativos ao controle social e religioso do chamado "catolicismo popular" entre as décadas de 1860 e 1880, já bastante examinados por farta bibliografia. Recomendo, neste sentido, a leitura de MARTINS (2005), NEVES (2009), MONNERAT (2009) e COSTA (2016).
}

Horizonte, Belo Horizonte, v. 14, n. 43, p. 975-1011, jul./set. 2016 - ISSN 2175-5841 
modelos tradicionais da iconologia cristã como reposta aos erros da modernidade. Interessante notar que a origem do nome "querubim” (keruv, em Hebraico) ainda é bastante obscura. Porém, parece convincente que tanto D. Macedo Costa quanto Silverio Capparoni, pensaram mais na imagem do repolho, tradução hebraica mais próxima de Keruv, que justamente enfatiza “invólucro" e "envolver", pois Deus se acomoda "no meio" dos querubins no plano celestial como representado na tela.

\section{Figura 2: Silverio Capparoni. Pai Eterno, c. 1881 (1,14 x 2, 26 cm), localizado no frontão do altar-mor da Catedral da Sé de Belém}

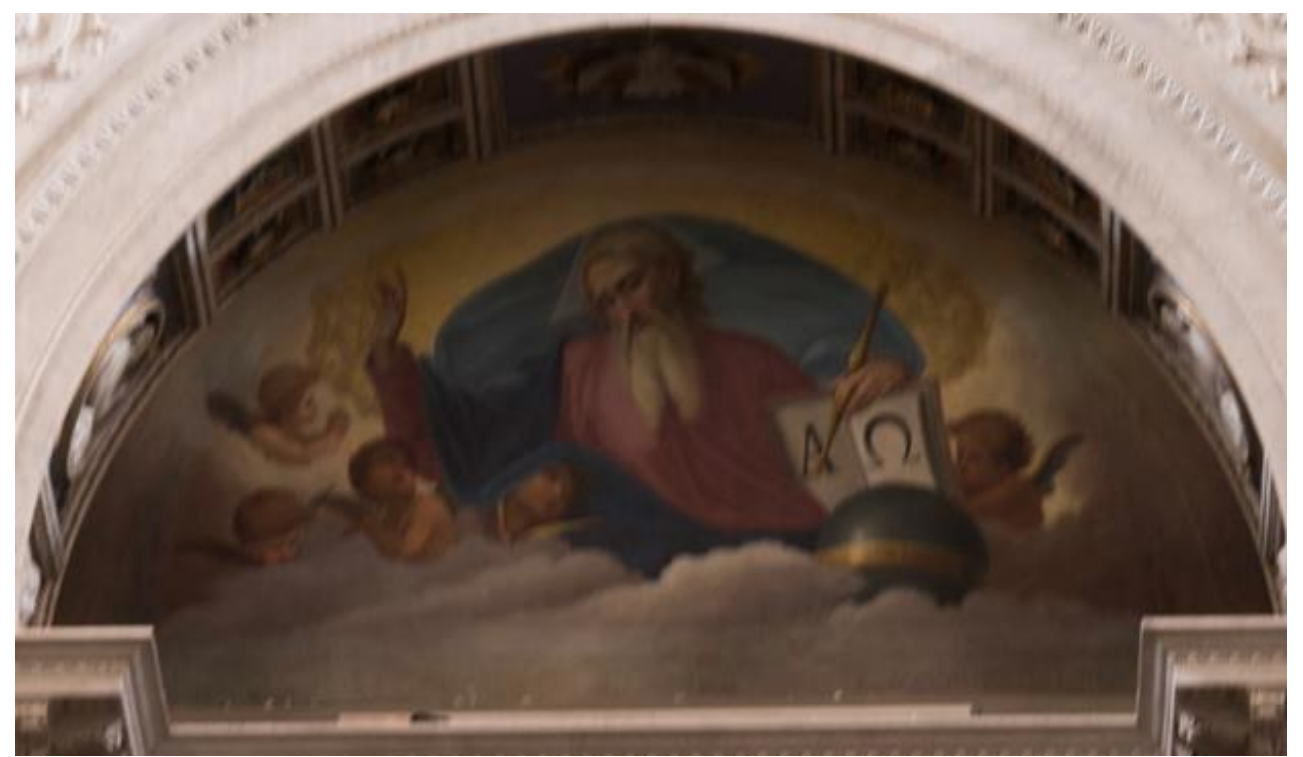

Fonte: Silvio Rodrigues, 2015.

Na representação de Capparoni, Deus imposta à mão esquerda um livro, em cujas páginas estão gravados o alfa e o ômega, declaração que retoma, segundo a tradição cristã, a unicidade entre o princípio do Deus Pai, no emblema do alfa, e o fim em Cristo, no emblema do ômega. Os textos que sustentam essa iconografia estão no primeiro capítulo do Evangelho segundo São João, com a sentença de que Deus (Pai e Filho) “está no princípio de tudo”, e que também tudo acompanha até ao fim do mundo, conforme o Apocalipse do mesmo evangelista. Segundo Valentino Pace, a imagem de Deus Supremo como alfa e ômega constitui uma das 
mais fortes representações artísticas do juízo final tanto no Oriente como no Ocidente (2006, p.12).

De cada um dos lados, sobressaem as estátuas em mármore de São Pedro e São Paulo, cujo aniversário de martírio fora celebrado em 1867, contando com a participação de centenas de prelados do mundo católico em Roma, incluindo, como já foi dito, o próprio bispo D. Macedo Costa. Certamente aqui o projeto de Carimini e do bispo paraense era o de ratificar a importância dos apóstolos Pedro e Paulo como fundadores da comunidade cristã de Roma, considerada a única do mundo fundada por mais de um apóstolo e a única do Ocidente instituída por um deles. A imagem teria que ensinar, propagar a fé e, mais do que isso, demonstrar o poder e a antiguidade da Igreja Católica sob o braço de Cristo e dos apóstolos. A escultura narrava, assim, a antiguidade da comunidade de Roma, congregação que teve o primado sobre todas as outras comunidades locais, como o bispado do Pará. O objetivo era o de ligar Belém a Roma. Nessa leitura, o ministério de Pedro, que continuamente exercido pelo Bispo de Roma (segundo o catolicismo romano), estaria, no presente, personificado na figura de Pio IX, do mesmo modo como o ministério dos outros apóstolos teria de ser cumprido pelos outros Bispos unidos a ele, como era o caso de Dom Macedo Costa. O papa, como sucedâneo de Pedro, seria a "cabeça" do colégio apostólico e do colégio episcopal. A sucessão papal vinda de Pedro teria começado, segundo rezava a tradição, com São Lino (67 d.C.) e, em 1871, na época da chegada do altar em Carimimi a Belém, era exercida obviamente por Pio IX, representado no monumento paraense por seu brasão pontifício em vista da própria ancestralidade da imagem de São Pedro. 
Figura 3: Brasão pontifício do Papa Pio IX feito em mármore e localizado na base esquerda do altar -mor da Catedral da Sé de Belém

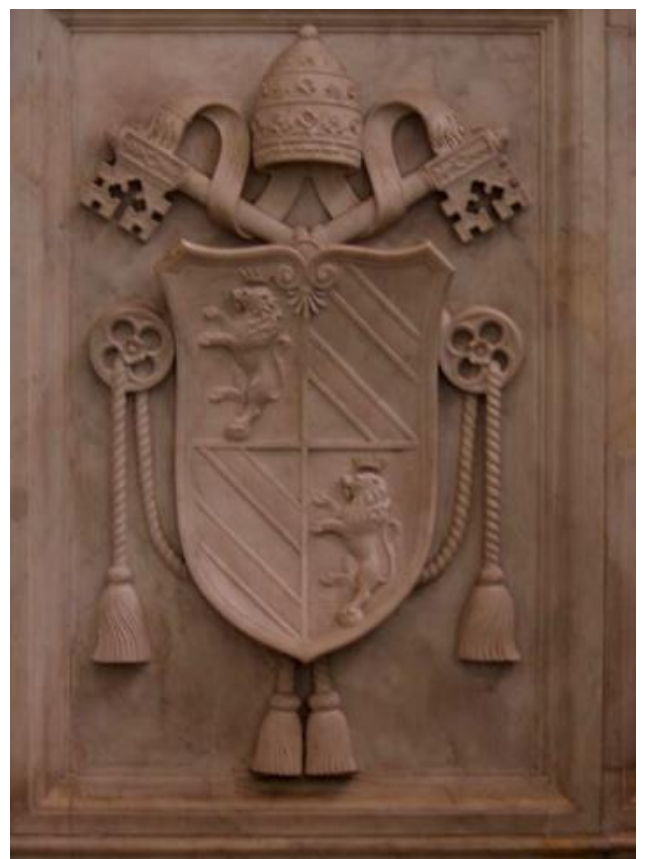

Fonte: Silvio Rodrigues, 2015.

Figura 4: Brasão episcopal do bispo Dom Antônio de Macedo Costa feito em mármore e localizado na base direita do altar-mor da Catedral de Belém

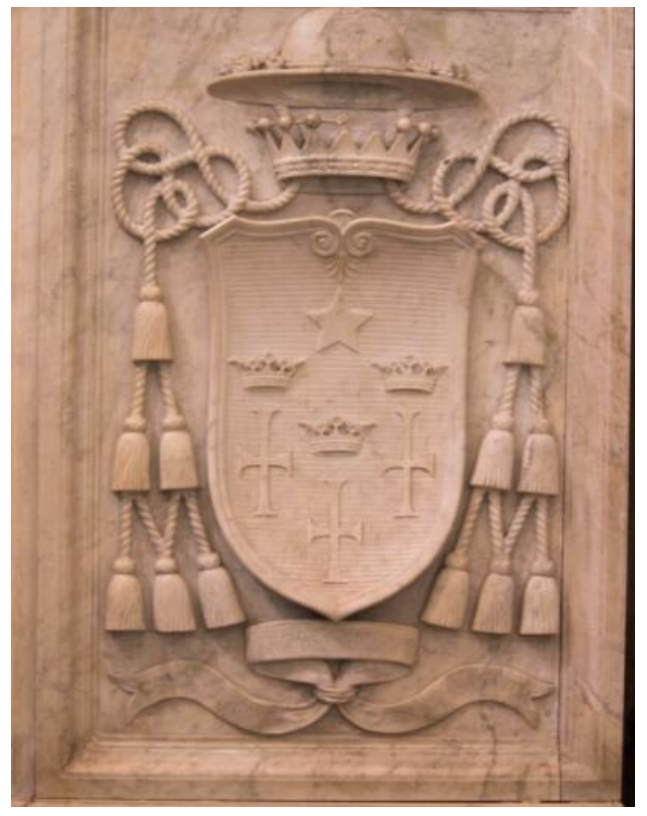

Fonte: Silvio Rodrigues, 2015. 
Essa leitura iconológica guardava um sentido histórico. Segundo essa visão, o próprio apóstolo Pedro havia atestado, numa narrativa do Evangelho, que exercera o seu ministério em Roma ao concluir a sua primeira epístola: "A [Igreja] que está em Babilônia9 ${ }^{9}$, eleita como vós, vos saúda, como também Marcos, meu filho" (PEDRO, 1: 5). Dom Macedo Costa ainda referiu como central a face martirizada de Pedro, na prisão e na sua crucificação (COSTA, 1894, p.238-240, 251).

\section{Figura 5: Estátua em mármore representando São Pedro, localizada na lateral esquerda do altar-mor da Catedral da Sé de Belém}

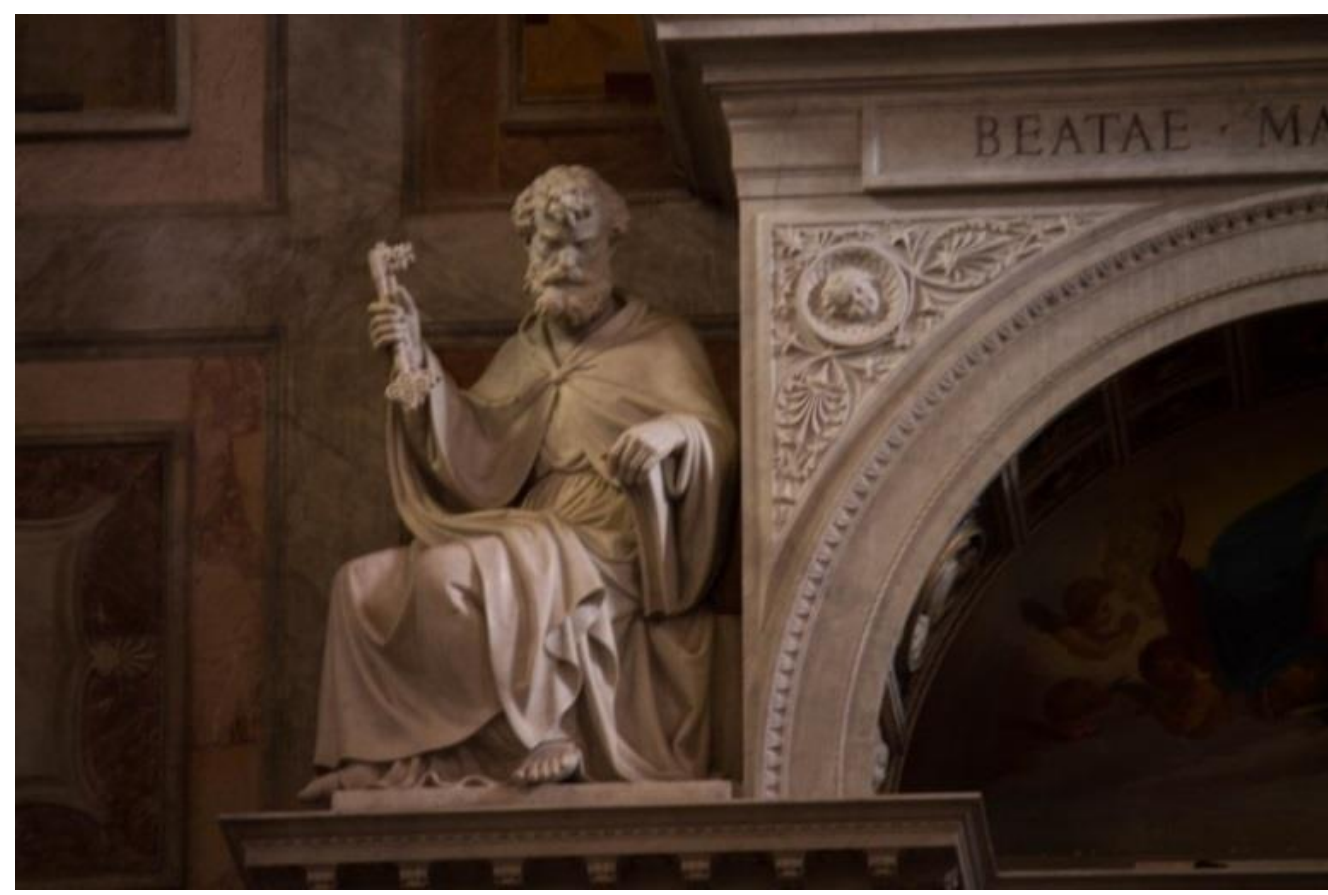

Fonte: Silvio Rodrigues, 2015.

Assim como Pedro, São Paulo ganhava, nas mãos de Carimini, o destaque que o cristianismo lhe dava desde suas primeiras épocas. Os significados eram vários: Paulo, cidadão romano convertido; o pregador que viajou pelo

\footnotetext{
${ }^{9}$ Trata-se da Igreja de Roma ou de culto ao Imperador Romano. Assim também o interpretaram todos os autores desde a Antiguidade, como abaixo, como sendo a Roma Imperial em sua imagem de decadência. $O$ termo não pode referir-se a Babilônia sobre o Eufrates, que jazia em ruínas ou à Nova Babilônia, como era frequentemente denominada da cidade de Selêucia, antiga capital do Império Selêucida, sobre o rio Tigre, ou à Babilônia Egípcia, como por vezes era citada Mênfis, tampouco a Jerusalém; deve, portanto referir-se a Roma, a única cidade que é chamada Babilônia pela antiga literatura cristã (ECK, 2007).
} 
mediterrâneo e pela Ásia Menor anunciando o evangelho de Cristo e o mistério de sua paixão, morte e ressurreição. Paulo, o mentor de uma teologia desenhada em epístolas que, ao lado dos Evangelhos, foram vistas pela hierarquia católica como fontes de todo pensamento, vida e mística cristãs. E, por fim, o mártir da Igreja. Sua morte em Roma continua tendo uma data incerta, mas alguns historiadores defendem ter ocorrido entre 64 e 67. (TRICOT, 1927, p.47). D. Macedo Costa, bem a propósito, costumava celebrar com missas solenes as duas festas litúrgicas do calendário católico em homenagem a São Paulo. A primeira em 25 de janeiro, tão antiga que fora instituída na Gália, no século VIII, para lembrar a conversão do Apóstolo e entrou no calendário romano no final do século X. A segunda, lembrando o seu martírio a 29 de junho, juntamente com o do Apóstolo São Pedro, já inserida no santoral católico muito antes da festa do Natal, desde o século IV, com o costume de celebrar neste dia três Missas. A ideia de D. Macedo Costa era a de repetir os gestos e as narrativas sagradas, com uma liturgia semelhante às que aconteciam em Roma, na basílica de São Pedro no Vaticano, na basílica de São Paulo fora dos Muros e nas catacumbas de São Sebastião, onde as relíquias dos dois Apóstolos tiveram de ser escondidas por algum tempo para subtraí-las à profanação, e onde se realizavam as três missas anuais em invocação do santo. Dom Macedo Costa, por seu turno, enfatizou em seu catecismo, as leituras sobre a conversão de São Paulo, sua primeira viagem apostólica e seu cativeiro e morte (COSTA, 1894, p.247-259). 
Figura 6: Estátua em mármore representando São Paulo, localizada na lateral direita do altar-mor da Catedral da Sé de Belém

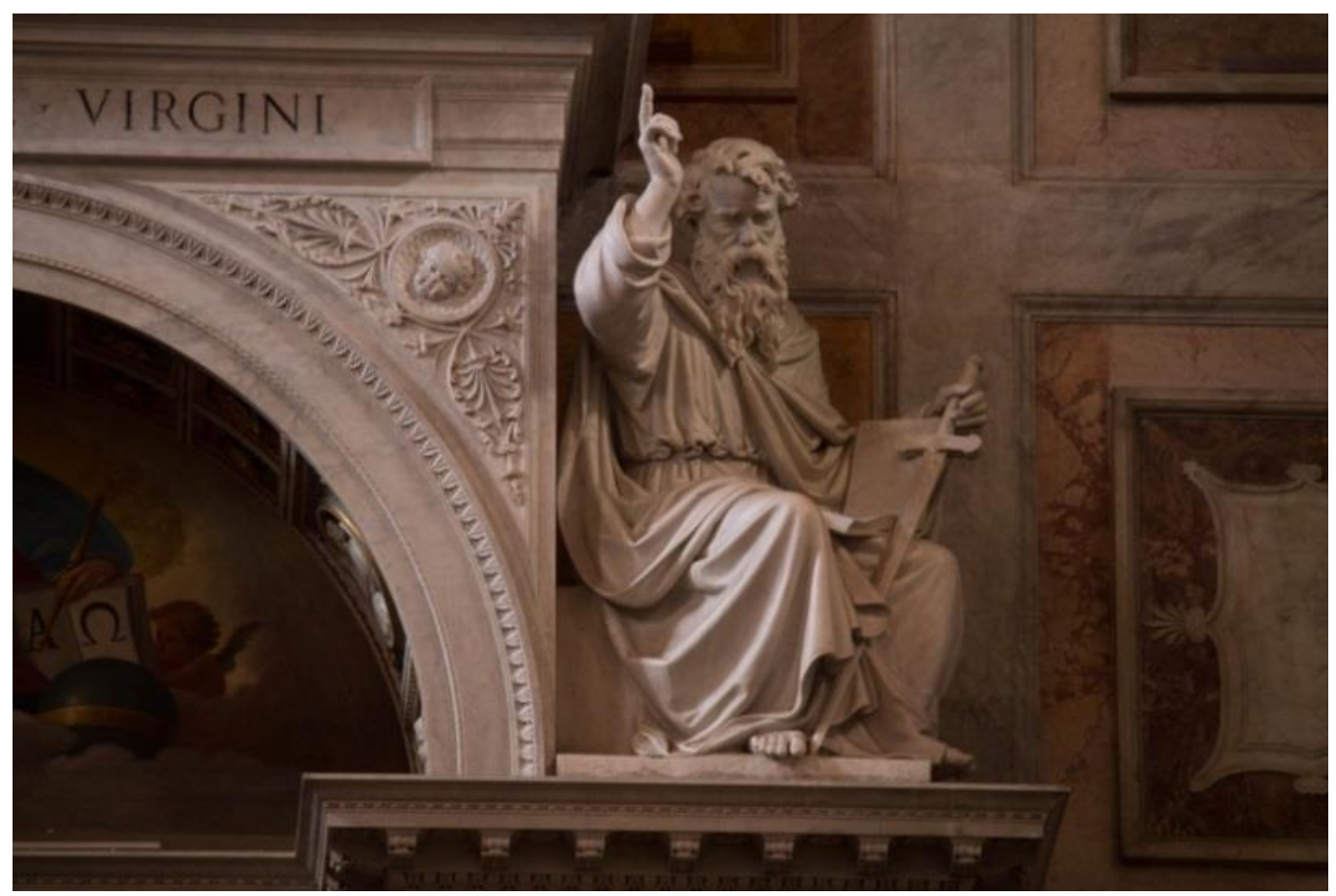

Fonte: Silvio Rodrigues, 2015 .

Talvez seja importante notar também, dado o destaque no altar da catedral, o fato de que, depois da Virgem Maria, são precisamente os Apóstolos Pedro e Paulo, juntamente com São João Batista, os santos comemorados mais frequentemente e com maior solenidade no ano litúrgico. Porém, num templo dedicado à Virgem Maria, as representações artísticas e religiosas e o conjunto de narrativas sagradas marianas teriam que ter destaque, seguindo os princípios assinalados por Pio IX na proclamação do dogma da Imaculada Conceição em 1854. Na moldura do tímpano em arco, em faixa reta, a inscrição "Beata Marie Virgo", que constitui a frase latina "Bem Aventurada Virgem Maria". Este título provém do cântico Magnificat (Lucas 1, 4-8). Dom Macedo Costa, que foi um importante incentivador, no Pará do século XIX, dos ofícios litúrgicos reformados com as novenas e litanias marianas e as solenidades de coroação de Nossa Senhora, demonstrou no altar, a antiguidade e tradição do Magnificat de Maria, considerado anterior à classificação litúrgica de santos (sancti) e bem-aventurados (beati). 
Portanto, o genitivo Beatae Mariae Virginis, muitas vezes aparece nos títulos oficiais de antigas igrejas e capelas dedicadas à Nossa Senhora, tanto em Roma, como em Lisboa ou Belém do Pará.

Essa narrativa, conforme aparece reiteradamente citada no calendário litúrgico paraense ao tempo de Dom Macedo, citado nos jornais A Estrella do Norte e A Boa Nova, entre as décadas de 1860 e 1880, era vivenciada em pelo menos quatro solenidades, três festas e três memórias marianas. As solenidades eram: Maria Santíssima, Mãe de Deus, no dia $1^{\circ}$ de janeiro; Anunciação do Senhor, no dia 25 de março; Assunção de Maria ao céu, no dia 15 de agosto; e Imaculada Conceição, no dia 8 de dezembro. As festas, eventos salvíficos, em que Maria esteve estreitamente unida a seu Filho, eram: Apresentação do Senhor e festa de Cristo e de Maria, no dia 2 de fevereiro; Visitação, no dia 31 de maio; Natividade de Maria, no dia 8 de setembro. As memórias, que eram festas de devoção e celebravam apenas um aspecto do Mistério da Salvação ou um título da Virgem Maria, eram: Nossa Senhora Rainha, no dia 22 de agosto; Nossa Senhora das Dores, no dia 15 de setembro; Apresentação de Nossa Senhora, no dia 21 de novembro; e o Imaculado Coração de Maria, no sábado após a Solenidade do Sagrado Coração de Jesus. Durante essas liturgias, o altar era enfeitado com flores, velas, alfaias e paramentos próprios para cada ofício.

No vértice do tímpano, ladeado por arcanjos adoradores, esculpidos em mármore branco de Carrara, um Jesus Cristo, ao mesmo tempo místico e sublime, em posição de pantocrator, traz à mão esquerda o livro dos Evangelhos e, com a mão direita, convida-nos a ler das sagradas páginas o verbo redentor: "Ego sum via, veritas et vita" (Eu sou o caminho, a verdade e a vida), em referência à sua própria narrativa na última Ceia e ao Evangelho de São João, 1: 6. Junto à imagem de Cristo aparecem os símbolos dos evangelistas: o leão de São Marcos e a águia de São João. Também aqui o programa iconológico aprofunda a simbologia sagrada. As representações de São Marcos como um leão e de São João com águia advêm de 
uma iconografia cristã derivada das visões proféticas contidas no Apocalipse de São João, 4: 7. O leão e a águia são duas das quatro criaturas, além do anjo e do boi, descritas como estando em volta do trono do Todo-Poderoso e são os símbolos dos quatro evangelistas. Esses seres tinham sido descritos antes pelo profeta Ezequiel, 1: 10.

\section{Figura 7: Estátua de mármore de Jesus Cristo Pantocrator ladeado por dois anjos adoradores, localizada no vértice do tímpano do altar de mármore da Catedral da Sé de Belém}

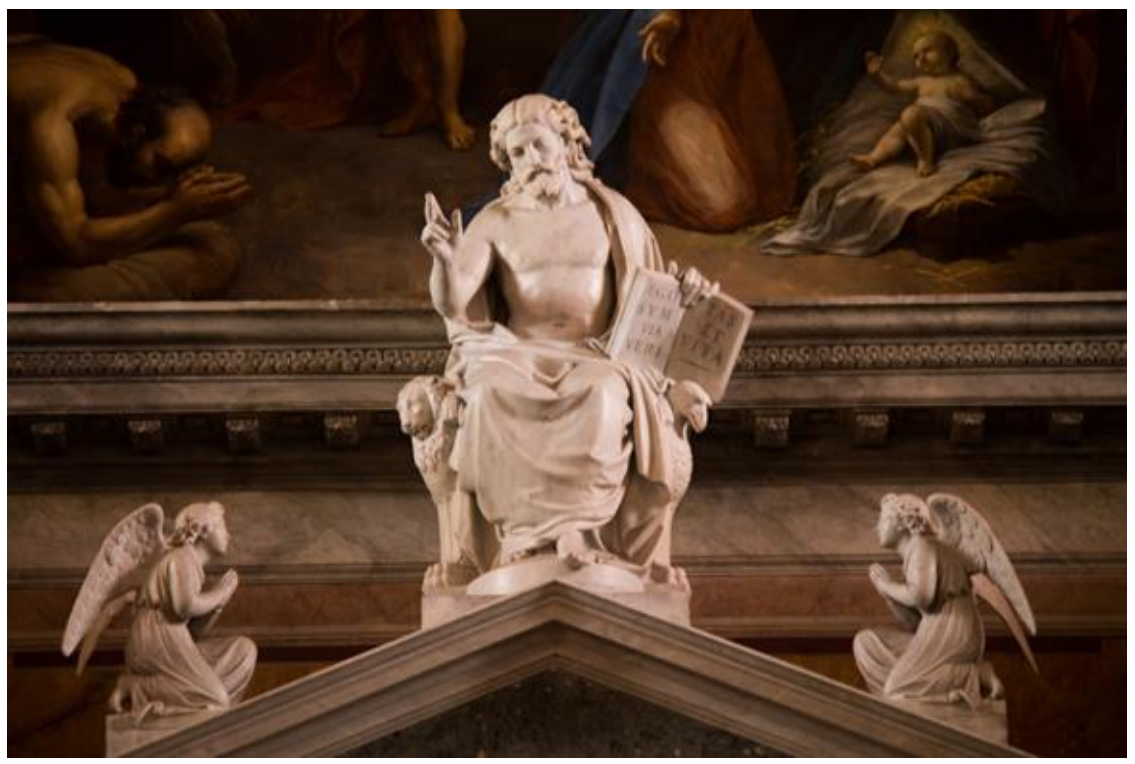

Fonte: Silvio Rodrigues, 2015.

A imagem de Cristo Pantocrator aparece no programa iconológico de Dom Macedo Costa com o objetivo de recuperar uma das representações mais antigas do cristianismo. De toda a imensa simbologia da tipologia iconográfica de Cristo Pantocrator, notamos que o bispo do Pará e Luca Carimini optaram por enfatizar dois elementos importantes da representação antiga, relidos agora os termos do Concílio Vaticano I (1869-1870), e as constituições dogmáticas já aqui referidas sobre a fé católica e sobre o primado e infalibilidade do Papa, quando se pronuncia ex-cathedra, em assuntos de fé e de moral. Por isso mesmo, Cristo é retratado com a mão direita que abençoa e o livro com as inscrições sagradas na 
mão esquerda. Sobre esse primeiro aspecto, na Igreja Oriental, sobretudo na bizantina, a bênção (em grego euloghia) é reservada ao bispo ou ao sacerdote que a pronuncia para abençoar uma ou mais pessoas, ou um objeto, fazendo um sinal da cruz e pronunciando ao mesmo tempo uma breve fórmula de bênção. A pedagogia ultramontana do século XIX procurou retomar e destacar esse papel sacerdotal como herança de Cristo. Na missa, a bênção mais solene é a que o sacerdote dá no fim da liturgia eucarística. Retomando o Pantocrator, a ideia era mostrar que o sacerdote não dá a bênção em nome próprio, mas transmite a bênção dada pelo próprio Cristo, com a mão direita que abençoa (SCHÖNBORN, 1994). No alto, ao centro, Cristo, como protagonista de sua igreja, cumpria exposição narrativa dos acontecimentos sagrados, dos encadeamentos discursivos da história da Igreja, das passagens literárias e artísticas por meio de uma narrativa visual.

\section{À guisa de conclusão}

Neste texto, buscamos destacar que os textos sagrados, as referencias doutrinárias e a própria liturgia serviram no contexto da reforma católica não apenas de amparo para fiéis católicos, mas também como fonte para arte e a decoração sacra, assim como campo de debate político entre clérigos, políticos e intelectuais. Isso significa dizer a história religiosa, o discurso literário e as artes plásticas se articulam no sistema dos objetos, no movimento das imagens e no próprio diálogo com os textos sagrados (BAUDRILLARD, 1978; WARBURG, 2010; AUERBACH, 2013). Traduzindo de outro modo, a história e as narrativas em torno de um objeto de arte, eivadas de significados e simbolismos sagrados, podem ser um campo importante de releitura dos textos seminais da religião, como nos parece ter sugerido, com muita propriedade, Robert Alter em The art of Biblical Narrative. Nesta obra, fica evidente o uso dos paralelismos, diálogos contrastivos e digressões na escala do tempo com objetivo de construções, reelaborações e recepções discursivas do texto bíblico. 
Acreditamos, portanto, que com o altar da Sé de Belém executado por Luca Carimini, o bispo D. Macedo Costa procurou reformular e dar novo sentido para a arte religiosa na Amazônia brasileira estabelecendo intercâmbios e reapropriações a partir de diretrizes propagadas de Roma e, ao mesmo tempo, com os movimentos políticos, intelectuais e religiosos amazônicos. Não se trata de transplantação e nem de eco dos modelos romanos, mas de adaptações, rearanjos e interações no campo artístico e pedagogico religioso. Para dar corpo a esse projeto, o prelado lançou mão do que havia de melhor na capital da arte ao tempo do pontificado de Pio IX e do contexto do risorgimento italiano, com minuciosa leitura de narrativas sagradas sob o viso da escultura e da pintura religiosa. Não foi, portanto, sem sentido a encomenda feita a um artista italiano do porte de Carimini que, para o historiador e teórico da arquitetura Paolo Portoghesi, representou o maior expoente da arquitetura romana da segunda metade do século XIX (PORTOGHESI, 1993, p.9). A iniciativa do bispo paraense, portanto, certamente faz parte de um longo e amplo processo histórico das relações entre o norte do Brasil e o ambiente artístico italiano nos campos político, social e artístico.

Há que ficar claro, também, que o Altar de Carimini se concebe aqui como texto narrativo de arte, como fonte de história e testemunho de uma época. Como produção artística é, a um só tempo, documento e monumento passível de múltiplas interpretações. Sua criação, permeada de conflitos e diversos pontos de vistas cotejados na imprensa da época, é também um projeto de memória do bispo, do papado e da própria Igreja brasileira reformada. De fato, entre rupturas e permanências, esse movimento que englobou a arte como um programa iconológico de pedagogia cristã faz parte de um diálogo que se irradia para frente e para trás da encomenda do altar de romano de Nossa Senhora de Belém. Nele, a decoração da Catedral do Pará deve ser lida como um pêndulo equidistante na história da arte sacra oitocentista no Norte do Brasil. 


\section{REFERÊNCIAS}

ALTAR DE MÁRMORE. A Constituição. Belém, p.1, 21 de setembro de 1880.

ALTER, Robert. The art of Biblical narrative. New York: Basic Books, 1981.

ANDERSON, B. Comunidades imaginadas. Reflexiones sobre el origen y la difusión del nacionalismo. México: Fundo de Cultura Económica, 1993.

AQUINO, Maurício de. O conceito de romanização do catolicismo brasileiro e a abordagem histórica da Teologia da Libertação. Horizonte. v. 11, n. 32, p. 1485-1505, 2013.

ARGAN, Giulio Carlo. História da arte italiana. São Paulo: Cosac e Naify, 2003, 3 vol.

AUERBACH, Erich. Mimesis: the representation of reality in Western. Introduction by Edward W. Said. Princeton: Princeton University Press, 2013.

AZZI, Riolando. O movimento brasileiro de reforma católica durante o século XIX.

Revista Eclesiástica Brasileira, Petrópolis, Vozes, v.34, n. 135, p. 646-662, 1974.

AZZI, Riolando. O altar unido ao trono: um projeto conservador. São Paulo: Edições Paulinas, 1992.

BARATA, Manuel. As primeiras ruas de Belém. Revista do Instituto Histórico e

Geográfico do Pará. Belém, v.6, n.6, p.231-235, 1931.

BARBAGALLO, Salvatore. Iconografia liturgica del Pantokrator. Roma: Pontificio Ateneo S. Anselmo, 1996.

BAUDRILLARD, Jean. Le système des objets. Paris: Gallimard, 1978.

BEOZZO, José Oscar. Irmandades, Santuários, Capelinhas de Beira de Estrada. Revista Eclesiástica Brasileira, Petrópolis, Vozes, v. 37, n. 148, p. 741-758, dez 1977.

BetTendorf, J. F. Cronica da Missão dos Padres da Companhia de Jesus no Estado do Maranhão. Rio de Janeiro: J. Leite, 1910.

BISPADO do Pará. O Apóstolo, sexta-feira, p.2, 22 de maio de 1874.

BOESPFLUG, François. Dieu et ses images: une histoire de l'Eternel dans l'art. Paris: Bayard, 2008.

CAPITELLI, Giovanna. Raccontare il sacro: la Galleria dei Santi e dei Beati in Vaticano. In: CAPITELLI, G.; MAZZARELLI, Carla (a cura). La pittura di storia in Italia, 17851870: ricerche, quesiti, proposti. Milano: Silvana editoriale, 2008, p.195-209. 
CAPITELLI, G.; MAZZARELLI, Carla. Los “pittores de Pío IX” en Santiago de Chile: os misterios del rosário para la iglesia de la Ricoleta Domenica (1870). In: GUZMÁN, F., MARTINES, J. M. (org.). Arte Americano e Independencia. Nuevas Iconografías. Quinta Jornada de Historia del Arte. Santiago del Chile: Museo Historico Nacional, 2010. p. 45-60.

CAPITELLI, G.; MAZZARELLI, Carla. Arte di Controrisorgimento: Pio IX e la "monumentomania" vaticana. In: MONTAUTO, Novella. et al (a cura di). Arte e politica. Firenzi: Mandragora, 2013. p.147-150.

CASTELNUOVO, Enrico; GINZBURG, Carlo. Centro e periferia. In: Storia dell'arte italiana. Questioni e metodi. Torino: Einaudi, 1979. p. 285-352.

CASTELNUOVO, Enrico. Arte, industria, rivoluzioni: temi di storia sociale dell'arte. Torino: Einaudi, 1985.

CASTELNUOVO, Enrico. La Pittura in Italia: l'Ottocento. Milano: Electa, 1991.

CONSOLI, Gian Paolo; PASQUALI, Susana. Roma: l'architettura della capitale. In: RESTRUCCI, Amerigo (a cura di). Storia dell'architettura italiana. L'Ottocento. Milano: Electra, 2005. p.230-271.

COSTA, Antônio de Macedo. Pio IX Pontífice Rei. Lisboa: Typographia de J. J. Carvalho, 1861.

COSTA, Antônio de Macedo. Resumo da historia biblica ou narrativas do Velho e Novo Testamento. Porto: Lello \& Irmão, 1894.

DAZZI, Camila. As relações Brasil-Itália no segundo Oitocentos: a recepção da crítica de arte carioca à obra dos pintores brasileiros na Itália (1880-1890). 19\&20. Rio de Janeiro, v. I, n. 2, ago. 2006.

DERENJI, Jussara. Desenhos setecentistas na Sé de Belém. Anais do Museu Paulista. São Paulo. v.19. n.2. p. 107-127, 2011.

DONATO, Maria Pia, CAPITELLI, Giovanna; LAFRANCONI, Matteo. Rome capitale des arts au XIXe siècle. Pour une nouvelle périodisation de l'histoire européenne des capitales culturelles. In: Charle, Christophe. (dir.). Les temps des capitales culturelles (XVIIIe-XXe siècles). Seyssel: Champ Valon, 2009. p. 65-99.

ECK, Werner. The Age of Augustus. Oxford: Blackwell Publishing, 2007.

ELIADE, Mircea. O sagrado e o profano. São Paulo: Martins Fontes, 2002.

FIGUEIREDO, Aldrin Moura de. Janelas do passado, espelhos do presente: Belém, arte, imagem e história. Belém: Museu de Arte de Belém, 2012. 
FIGUEIREDO, Aldrin Moura de. Portugueses, italianos e franceses nos círculos artísticos de Belém do Pará (1880-1920). In: ARRUDA, J. J. de Andrade et al (orgs.). De colonos a imigrantes: i(e)migração portuguesa para o Brasil. São Paulo: Alameda, 2013. p. 549561.

GOMBRICH, Ernst. The Nineteenth Notion of a Pagan Revival. In: WOODFIELD, Richard (ed.). Art history as cultural history. New York: The Gordon and Breach, 2001. p. 5563 .

GROSS, Michael. Kulturkampf and Unification: German Liberalism and the War against the Jesuits. Central European History, Vol. 30, No. 4, p. 545-566, 1997.

GUIA D'ITALIA: Roma. Milano: Touring Club Italiano, 2002.

GUINZBURG, Carlo. O fio e o rastro: verdadeiro, falso e fictício. São Paulo: Companhia das Letras, 2007.

GUZMÁN. Fernando. L’arte di Roma nel Chile del XIX secolo. Un elemento delle stragie de representazione dell'identità nacionale. Il caso deglhi altari. In: CAPITELLI, G.; GRANDESSO, S.; MAZZARELLI, C. (a cura di). Roma fuori di Roma: L'esportazione dell'arte moderna da Pio VI all'Unità d'Italia (1775-1870). Roma, Campisano Editore, 2012. p. $419-438$.

JOSEPHUS, Flavius. Antichità giudaiche. Torino: Unione Tip. Ed. Torinese, 1998.

LEAL, Américo. A igreja da Sé. Belém: Falangola, 1979.

L'ESPOSIZIONE ROMANA delle opere di ogni arte eseguite pel culto cattolico: giornale illustrato. Roma: Stabilimento Tipografico, 1870.

LUSTOSA, Dom Antônio de Almeida. Dom Macedo Costa (Bispo do Pará). Belém: Secretária de Estado da Cultura, 1992.

MARTINA, Giacomo. Pio IX (1867-1878). Roma: Pontificia Università Gregoriana, 1990.

MARTINS, Karla. O Sol e a Lua em tempo de eclipse: a reforma catolica e as questões politicas na Provincia do Grão-Para (1863-1878). Dissertação de mestrado (História). Campinas: UNICAMP, 2001.

MARTINS, Karla. Civilização Católica: D. Macedo Costa e o Desenvolvimento da Amazônia na segunda metade do século XIX. Revista de História Regional, v. 7, n. 1, p. 73-103, 2002.

MARTINS, Karla. Cristóforo e a Romanização do Inferno Verde: as propostas de D. Macedo Costa para a civilização da Amazonia (1860-1890). Tese de doutorado (História). Campinas: UNICAMP, 2005. 
MAUÉS, Raymundo Heraldo. Tensão constitutiva do catolicismo: catolicismo popular e controle eclesiástico. Tese de doutorado (Antropologia). Rio de Janeiro: Museu Nacional/UFRJ, 1987.

MAUÉS, Raymundo Heraldo. As atribulações de um doutor eclesiástico na Amazônia na passagem do século XIX ou Como a política mexe com a Igreja Católica. Revista de Cultura do Pará, v. 12, n.1, p. 61-79, 1991.

MAUÉS, Raymundo Heraldo.A categoria jesuíta no embate entre liberais e católicos ultramontanos no Pará do Século XIX. Páginas de História. Belém, v. 1, n.1, p. 1-15, 1997.

MAUÉS, Raymundo Heraldo. Padres e bispo em conflito: o processo de "romanização" na Amazônia. Revista Anthropológicas. Recife, v. 2, n.2, p. 105-135, 1997a.

MAUÉS, Renata. As pinturas sobre tela da Catedral de Belém: universo visual e trajetória de restauro. 19\&20. Rio de Janeiro, v. VI, n. 3, jul./set. 2011.

MEIRA FILHO, Augusto. Nossa Senhora de Belém. Belém: Imprensa Oficial, 1971.

MONNERAT, Patrícia C. S. Festa e conflito: D. Antônio e a Questão de Nazaré (18611878). Dissertação de mestrado (História). Niterói: UFF, 2009.

NEVES, Fernando A. de F. Solidariedade e conflito: Estado Liberal e Nação Católica no Pará sob o pastorado de Dom Macedo Costa (1862-1889). Tese de doutorado (História). São Paulo: Pontifícia Universidade Católica, 2009.

OAKLEY, Francis. The Conciliarist Tradition. Oxford: Oxford University Press, 2003.

OLIVEIRA, Pedro Ribeiro de. Catolicismo Popular e Romanização do Catolicismo Brasileiro. Revista Eclesiástica Brasileira. Petrópolis, v.36, n. 141, p. 131-141, 1976.

PACE, Valentino (a cura di). Alfa e omega: il giudizio universale tra Oriente e Occidente. Castel Bolognese: Itaca, 2006.

PINTO, Antônio Rodrigues de Almeida. O Bispado do Pará. Annaes da Bibliotheca e Archivo Público do Pará. Belém, tomo 5, p. 5-191, 1906.

PITA, Sebastião da Rocha. História da América portuguesa. Belo Horizonte: Itatiaia; São Paulo: Edusp, 1976.

PORTOGHESI, Paolo. Prefazione. In: PRIORI, Giancarlo; TABARRINI, Marisa. Luca Carimini (1830-1890). F. C. Panini, 1993, pp. 1-9.

PRIORI, Giancarlo; TABARRINI, Marisa. Luca Carimini (1830-189o). Modena: F. C. Panini, 1993. 
RIO BRANCO, Barão. Obras do Barão do Rio Branco VI: efemérides brasileiras. Brasília: Fundação Alexandre de Gusmão, 2012.

RODRIGUES, Silvio Ferreira. Todos os caminhos partem de Roma: arte italiana e romanização entre o Império e a República em Belém do Pará (1867-1892). Tese de Doutorado (História). Belém: Universidade Federal do Pará, 2015.

SANTIROCCHI, Ítalo. Uma questão de revisão de conceitos: Romanização, Ultramontanismo, Reforma. Temporalidades. v.2, n.2, p.24-33, 2010.

SANTOS, João. A romanização da igreja católica na Amazônia (1840-1880). In:

HOORNAERT, Eduardo (org.). História da Igreja na Amazônia. Petrópolis: Vozes, 1992.

SARGES, Maria de Nazaré. Belém: riquezas produzindo a belle-époque (18701910). Belém: Paka-Tatu, 2000.

SERAFINI, Alberto. Pio Nono: Giovanni Maria Mastai Ferretti: dalla giovinezza alla morte nei suoi scritti e discorsi editi e inediti. Città del Vaticano: Libreria Poliglotta Vaticana, 1958, 2 vols.

SCHÖNBORN, Christoph von. God's human face: the Christ-icon. San Francisco: Ignatius Press, 1994.

THORNTON, Francis Beauchesne. Cross upon cross: the life of Pope Pius IX. New York: Benziger Bros, 1955.

TRICOT, Abbe. Saint Paul, apốtre des gentils. Paris: Bloud \& Gay, 1927.

TURCO, Maria Grazia. Interventi nelle cappelle romane durante il XIX secolo. In: SETTE, Maria Pietra (a cura di). Restauro architettonico a Roma nell'Otoccento. Roma: Bonsignori Editore, 2007.

VASTA, Daniela. La pittura sacra in Italia nell'Ottocento: Dal Neoclassicismo al Simbolismo. Roma: Gangemi Editore, 2012.

WARBURG, Aby. Atlas Mnemosyne. Tradução Joaquim Chamorro Melke. Madrid: Ediciones Akal, 2010. 